\title{
Economics of Preparation of Restructured Chicken Meat Blocks Extended with Different Vegetative Extenders
}

\author{
O.P.Malav*, B.D.Sharma, S.Talukder and R.R.Kumar
}

Division of Livestock Products Technology, Indian Veterinary Research Institute, Izatnagar, UP-243122

\begin{abstract}
Rapid urbanization and change in life style have increased demand for tasty, convenience and designer meat products; however, high cost of these products makes it difficult for an average consumer to include these products in their diet. Therefore the objective of present study is the production of low-cost meat products utilising vegetative extenders and comparison of production cost of extended products with the control product. Restructured Chicken Meat Blocks (RCMB) were prepared from a standardized formulation and were extended with optimized level of vegetative extenders viz., lentil flour, sorghum flour, potato, water chestnut flour and extender blend. Optimization of levels of extenders was done by different experiments based on sensory attributes and those having sensory status closer to control were selected. The cost of RCMB after replacement of lean meat with selected level of vegetative extenders and extender blend were compared among themselves to determine the most economic preparation. It was found that extended RCMB were cheaper than control products and among the extended RCMB least cost was for extender blend incorporated RCMB. The cost for extender blend extended RCMB and sorghum flour added $\mathrm{RCMB}$ were almost same but these were lower than potato, lentil flour and water chestnut flour added RCMB due to their higher yields and high level of replacement of lean meat. Thus it was concluded that formulation with extension of $15 \%$ extender blend at the cost of lean meat was most economic among the tested vegetative extenders.
\end{abstract}

Keywords: Restructured chicken meat blocks; Vegetative extenders; Economics; cost; Extender blend

\section{Introduction}

There is immense need to supply of animal proteins at reduced cost in the diet of common mass to fulfill the dietary requirement of proteins.The ICMR recommendation for protein consumption of $1 \mathrm{gm} /$ $\mathrm{Kg}$ body wt/day with Net Protein Utilization (NPU) of 65 could be achieved only by introducing the animal proteins in the form of meat in regular diet. Poultry industry, a fast growing sector now a days in India, may ensure the supply of proteins ofhigh biological value at low cost. India ranks fifth in chicken meat and 3rd in egg with production figure of 3.2 million tonnes of chicken meat and 67 billion eggs, in the world [1].Globally, poultry meat has become a mass consumer product due to its cost competitiveness, nutritional quality, universal availability and absence of religious taboos tagged with it.

Modern consumers are no longer satisfied with the traditional meat products. Rapid urbanization and change in life style have increased demand for more nutritious and ready to eat meat products [2]. Novel processing techniques for meat resulted into the production of meat products which are tasty and convenient with superior sensory qualities. However, high cost of these products makes it difficult for an average consumer to use these products regularly in their diet. Therefore development of technology for production of low-cost meat products is need of the hour. Production of more affordable, cheap and popular meat products can be achieved by careful selection and reformulation with ingredients from vegetative sources $[3,4]$.

Among the non-communised meat products, restructured products have been a choice for many people because of resemblance with hot processed meat. Restructuring is the method in which meat is partially or completely disassembled and then reassembled and then reformed into same or different form, which is called restructured products. Restructuring has the advantages of convenience in preparation and economy in the production due to which the restructured products are becoming important components of the processed meat industry.
Restructured meat products are made by extraction of muscle protein using salt and phosphate which forms a heat set protein gel upon subsequent cooking [5].

The non-meat ingredients from vegetative sources as filler, binder or extenders in cooked meat products can also improve the appearance, palatability, texture and functionality of the finished products along with reduction of cost [6-10]. Along with nutritive value and sensory acceptability of meat product, economics is also very important criteria that determine the marketability of any product. Therefore in present study the production cost of RCMB utilising optimum level of vegetative extendersviz., lentil flour, sorghum flour, potato, water chestnut flourand most acceptable extender blend was determined and compared with control, to conclude and suggest one particular extender or one suitable blend for the economic production of RCMB.

\section{Materials and Methods}

This research work is the part of M.V.Sc. Thesis of first author submitted to deemed university, Indian Veterinary Research Institute (IVRI), Izatnagar, UP, India in year 2012.

Chicken Birds (White Leghorn)was procured from Central Avian Research Institute, Izatnagar and dressed and deboned manually in the

*Corresponding author: O.P.Malav, Division of Livestock Products Technology Indian Veterinary Research Institute, Izatnagar, UP-243122, India, Tel: +91581 2303682; Email: drmalav_vet2007@rediffmail.com; ani1964.a@gmail.com

Received October 17, 2013; Accepted November 28, 2013; Published December 09, 2013

Citation: Malav OP, Sharma BD, Talukder S, Kumar RR (2013) Economics of Preparation of Restructured Chicken Meat Blocks Extended with Different Vegetative Extenders. J Food Process Technol 4: 282. doi:10.4172/21577110.1000282

Copyright: $\odot 2013$ Malav OP, et al. This is an open-access article distributed under the terms of the Creative Commons Attribution License, which permits unrestricted use, distribution, and reproduction in any medium, provided the original author and source are credited. 
experimental abattoir of Division of Livestock Products Technology, IVRI, Izatnagar. Deboned meat was packed in clean polyethylene bags and frozen at $-20^{\circ} \mathrm{C}$ until use. Analar and food grade chemicals were procured from Qualigens, Mercks and BDH. Refined salt (Tata Chemicals Ltd., Mumbai), refined wheat flour (maida), lentil flour, sorghum flour, potato, water chestnut flour, Low density polyethylene films (200 gauges) bags, onion and garlic were procured from local market of Bareilly (U.P.). To prepare condiment, onion and garlic were peeled off, cut into small pieces and homogenized in a mixer to obtain a fine paste. Spices prepared in laboratory as per pre-standardized formulation.

\section{Preparation of RCMB}

For optimization of level of either of the extender and extender blend, replacement of lean meat in control formulation was made at three different levels. Based on physico-chemical attributes and sensory characteristics the optimum level of replacement was adjudged as $6 \%$ lentil flour (1:1 hydration, w/w), 9\% sorghum flour [(1:1 hydration, $\mathrm{w} / \mathrm{w})[11], 6 \%$ potato (boiled and mashed), $10 \%$ water chestnut [(1:1 hydration, w/w) [12] and extender blend $C$, that was [5\% lentil flour (1:1 hydration, w/w), $5 \%$ sorghum flour (1:1 hydration, w/w), 5\% potato (boiled and mashed)].

Extended RCMB were prepared by replacing the lean meat in pre-standardizedformulation and processing conditions [11,12] with optimum level of extenders and extender blend C.

\section{Formulation}

Lean meat (78\%), Chilled water (10\%), Condiments (5\%), Refined wheat flour (3\%), Salt (1.8\%), STPP (0.3\%), Nitrite (150 ppm) and dry spices $(1.9 \%)$.

Meat was cut manually into $1 \mathrm{~cm}$ cubes and put into paddle mixer (Hobart Co. N 50G). Sodium nitrite, sodium tripolyphosphate and salt were dissolved in chill water, then added to meat and massaged for 1.5 minutes. Condiments, Refined wheat flour (maida), dry spices and optimum level of either extender or extender blend to the mixture and massaged for 1 minute till the tacky exudate formed. Batter was removed and filled into aluminium moulds ( $75 \mathrm{~mm} \times 75 \mathrm{~mm} \times 60 \mathrm{~mm}$ ), these moulds were kept in steam cooker and cooked for 45 minutes (till the internal temperature reaches to $72^{\circ} \mathrm{C}$ ) without pressure. Meat blocks were removed from moulds after cooking, cooled to room temperature $\left(28^{\circ} \mathrm{C}\right)$ and cut into slices of $7 \mathrm{~mm}$ with food slicer (Electrolux $\mathrm{H} 300$ ). Cooled sample of each treatment was assigned for analysis.

The extended RCMB with four different vegetative extenders and a extender blend at their selected levels were subjected to sensory evaluation by a minimum of seven experienced panelists using 8 point descriptive scale [13]where $8=$ extremely desirable and $1=$ extremely undesirable. The preparation cost of extended RCMB were calculated considering the ingredients and processing conditions utilized in the preparation of product to finally determine the most economic extended RCMB formulation.

\section{Statistical analysis}

The experiment was replicated three times and the data generated were analyzed by statistical methods of one way ANOVA and Mean \pm S.E using SPSS software package developed as per the procedure of Snedecor and Cochran [14].

\section{Result and Discussion}

The comparative cost for formulation of $50 \mathrm{Kg}$ control and extended RCMBis presented in Table 1. It includes the cost of raw materials required for preparation of restructured chicken meat blocks which are deboned chicken meat, table salt, spices mixture, condiments, refined wheat flour, STPP, sodium nitrite and the cost of vegetative extenders viz. lentil flour, sorghum flour, potato, and water chestnut flour. In addition transportation cost for the purchase of raw materials was included. The retail prices for these ingredients are relatively stable in our marketing system. However, the cost of these ingredients can be lowered if purchased in bulk quantities from distributors/ whole sale agents that may further reduce the cost of production. The formulation cost of $50 \mathrm{Kg}$ product was Rs (Indian rupee) 8286, 7661, $7420,7701,7466$ and 6880 for control and treatments including lentil flour, sorghum flour, potato, water chestnut flour and extender blend respectively. It was found that formulation cost for extended RCMB were less than control product and among the extended RCMB least formulation cost was for extender blend incorporated RCMB. Less formulation cost for extended RCMB as compared to control product was due to the fact that all the vegetative extenders utilised at their optimum level were much cheaper than deboned chicken meat and among extended RCMB lowest formulation cost for extender blend incorporated RCMB was due to replacement of lean meat at $15 \%$ level in standardised formulation.

Overhead cost involved in product preparation is presented in Table 2, it includes labour charges (skilled and unskilled), electricity charges, rent of building, packaging material cost, water charges, maintenance cost and equipment depreciation (@ 10\% per annum). It was similar for control and extended RCMB and was found to be Rs

\begin{tabular}{|c|c|c|c|c|c|c|c|c|c|c|c|c|c|}
\hline \multirow[t]{2}{*}{ Ingredients } & \multirow[t]{2}{*}{$\begin{array}{l}\text { Rate Rs/ } \\
\text { kg }\end{array}$} & \multicolumn{2}{|c|}{ Control } & \multicolumn{2}{|c|}{ Lentil (6\%) } & \multicolumn{2}{|c|}{ Sorghum $(9 \%)$} & \multicolumn{2}{|c|}{ Potato $(6 \%)$} & \multicolumn{2}{|c|}{$\begin{array}{c}\text { Water chestnut } \\
(10 \%)\end{array}$} & \multicolumn{2}{|c|}{ Extender blend (C) } \\
\hline & & Qt. (Kg) & Rs & Qt (Kg) & Rs & Qt. (Kg) & Rs & Qt. (Kg) & Rs & Qt. (Kg) & Rs & Qt. (Kg) & Rs \\
\hline Lean chicken & 200 & 39 & 7800 & 36 & 7200 & 34.5 & 6900 & 36 & 7200 & 34 & 6800 & 31.5 & 6300 \\
\hline Lentil & 50 & - & - & 1.5 & 75 & - & 0 & - & - & - & - & 1.25 & 62.5 \\
\hline Sorghum & 15 & - & - & - & - & 2.25 & 33.75 & - & - & - & - & 1.25 & 18.75 \\
\hline Potato & 5 & - & - & - & - & - & - & 3 & 15 & - & - & 2.5 & 12.5 \\
\hline Water chestnut & 80 & - & - & - & - & - & - & - & - & 2.25 & 180 & - & - \\
\hline Spice mix & 250 & 0.95 & 237.5 & 0.95 & 237.5 & 0.95 & 237.5 & 0.95 & 237.5 & 0.95 & 237.5 & 0.95 & 237.5 \\
\hline Condiments & 22 & 2.5 & 55 & 2.5 & 55 & 2.5 & 55 & 2.5 & 55 & 2.5 & 55 & 2.5 & 55 \\
\hline Refined wheat flour & 15 & 1.5 & 22.5 & 1.5 & 22.5 & 1.5 & 22.5 & 1.5 & 22.5 & 1.5 & 22.5 & 1.5 & 22.5 \\
\hline Curing solution & 68 & 1.0575 & 71 & 1.0575 & 71 & 1.0575 & 71 & 1.0575 & 71 & 1.0575 & 71 & 1.0575 & 71 \\
\hline Transportation cost & - & - & 100 & - & 100 & - & 100 & - & 100 & - & 100 & - & 100 \\
\hline Total & - & - & 8286 & - & 7661 & - & 7420 & - & 7701 & - & 7466 & - & 6880 \\
\hline
\end{tabular}

Table 1: Comparative cost for formulation of $50 \mathrm{Kg}$ control and extended RCMB. 
Citation: Malav OP, Sharma BD, Talukder S, Kumar RR (2013) Economics of Preparation of Restructured Chicken Meat Blocks Extended with Different Vegetative Extenders. J Food Process Technol 4: 282. doi:10.4172/2157-7110.1000282

Page 3 of 3

\begin{tabular}{|c|c|}
\hline Labour charges & $\begin{array}{c}\text { Skilled staff }=200 \times 1=₹ 200 / \text { day } \\
\text { Unskilled staff }=140 \times 2=₹ 280 / \text { day } \\
\text { Total }=₹ \mathbf{4 8 0} / \text { day }\end{array}$ \\
\hline Electric charges & $\begin{array}{l}26 \mathrm{KWh} \times \mathrm{Rs} .3 .5 / \mathrm{KWh} \\
=\mathrm{Rs} .88 .9 \sim \text { ₹ } 89 / \text { day }\end{array}$ \\
\hline Equipment depreciation ${ }^{*}$ & $\begin{array}{c}\text { @ } 10 \% \text { per annumi.e. }=\text { Rs. } 11,020 \text { /annum } \\
\text { i.e. }=₹ 31.19 \sim 32.0 / \text { day }\end{array}$ \\
\hline Cost of Packaging material & $(8 " \times 6 "$ LDPE pouches $)=200 \times 0.60=₹ 120.00$ \\
\hline Water charges (200 litre) & $=200 \times 0.06=₹ 12.00$ \\
\hline Maintenance cost & $=₹ 400$ per day \\
\hline Rent of building & $=₹ 200$ per day. \\
\hline TOTAL OVERHEAD COST & $\cong ₹ 1333$ \\
\hline
\end{tabular}

Table 2: Overhead Production Cost of Approximately $50 \mathrm{Kg} \mathrm{RCMB.}$

\begin{tabular}{|c|c|c|c|c|c|c|}
\hline Parameter & Control & $\begin{array}{c}\text { Lentil } \\
\mathbf{( 6 \% )}\end{array}$ & $\begin{array}{c}\text { Sorghum } \\
\mathbf{( 9 \% )}\end{array}$ & $\begin{array}{c}\text { Potato } \\
\mathbf{( 6 \% )}\end{array}$ & $\begin{array}{c}\text { Water } \\
\text { chestnut } \\
(\mathbf{1 0 \% )}\end{array}$ & $\begin{array}{c}\text { Extender } \\
\text { blend (C) }\end{array}$ \\
\hline $\begin{array}{c}\text { Cost of formulation } \\
(\text { ₹) }\end{array}$ & 8286 & 7661 & 7420 & 7701 & 7466 & 6880 \\
\hline $\begin{array}{c}\text { Overhead } \\
\text { Production Cost (₹) }\end{array}$ & 1333 & 1333 & 1333 & 1333 & 1333 & 1333 \\
\hline $\begin{array}{c}\text { Total (₹) } \\
\text { expenditure }\end{array}$ & 9619 & 8994 & 8753 & 9034 & 8799 & 8213 \\
\hline \begin{tabular}{c} 
Product yield (Kg) \\
\hline Actual cost per Kg \\
product (₹)
\end{tabular} & 42 & 45.5 & 47.5 & 42.5 & 46 & 45 \\
\hline
\end{tabular}

Table 3: Production cost of RCMB.

1333 for the production of $50 \mathrm{Kg}$ product. Similar overhead cost for restructured meat dough preparation was reported by Kumar [15].

In Table 3 production cost of RCMB in actual considering the yield has been presented. The product yield was around $86 \%, 93 \%$, $96 \%, 87 \%, 94 \%$ and $92 \%$ for control and treatment products including lentil, sorghum, potato, water chestnut and extender blend respectively $[11,12]$. However, a safety margin of 1 to $2 \%$ should be considered to compensate the losses that might occur during various steps of processing, packaging and marketing, considering a final yield at $84 \%, 91 \%, 95 \%, 85 \%, 92 \%$ and $90 \%$ for control and treatments.Total expenditure for the preparation of $50 \mathrm{~kg}$ RCMB was Rs 9619, 8994, $8753,9034,8799,8213$ and the product yield $(\mathrm{Kg})$ was $42,45.5,47.5$, $42.5,46,45$ for control and treatments including lentil, sorghum, potato, water chestnut and extender blend respectively. Therefore the cost of $1 \mathrm{~kg}$ product comes to be Rs. 229, 198, 184, 213, 191, and 183 for control and treatments including lentil, sorghum, potato, water chestnut and extender blend respectively.

As the sensory scores for all the five sets of RCMB were same the RCMB with maximum yield and lowest cost of formulation was adjudged most economic. This study indicated that incorporation of extenders at their optimum level viz. lentil, sorghum, potato, water chestnut and extender blend resulted reduction in cost of RCMB by Rs 31, 45, 16, 38 and 46 per Kg respectively as compared to control.

\section{Acknowledgement}

We sincerely thank to The Director, IVRI for all the financial aid provided for the successful completion of this research work.

\section{References}

1. FAO (2009) Production Yearbook. Food and Agricultural Organisation, Rome.

2. Deogade $A H$, Zanjad PN, Raziuddin M (2008) Value Added Meat Products. Vet. World 1: 88-89.

3. Huang SC, Shiau CY, Liu TE, Chu CL, Hwang DF (2005) Effects of rice bran on sensory and physico-chemical properties of emulsified pork meatballs. Meat Sci 70: 613-619.

4. YÄ \pm Imaz I, DaÄŸIÄ \pm oÄŸlu O (2003) The effect of replacing fat with oat bran on fatty acid composition and physicochemical properties of meatballs. Meat Sci 65: 819-823.

5. Rajharjo S, Dexter DR, Worfel RC, Sofos JN, Solomon MB (1994) Restructuring veal steaks with salt/phosphate and sodium alginate/calcium lactate. J Food Sci 59: 471-473.

6. Akoh CC (1998) Fat replacers. Food Technol 52: 47-53

7. Iyengar R, Gross A (1991) Fat substitutes. Biotechnology and food ingredients. New York: Van Nostrand Reinhold.

8. Jimenez C F (1996) Technologies for developing lowfat meat products. Trends Food Sci. Technol 7: 41-48.

9. Mendoza E, Garcia ML, Casas C, Fernandez MF, Selgas MD (1998a) Utilizacion de proteinascomosustitutos de grasas en productoscarnicos. AlimentacioonEquiposyTecnologia 7: 87-92.

10. Mendoza E, Garcia ML, Casas C, Fernandez MF, Selgas MD (1998b) Utilizacion de hidratos de carbonocomosustitutos de grasas en productoscarnicos. AlimentacioonEquiposyTecnologia 7: 55-60.

11. Malav OP, Sharma BD, Gokulakrishnan P, Talukder S, Kumar RR (2012a) Quality characteristics of functional restructured chicken meat blocks extended with sorghum flour. Ind Vet J 89: 49-52.

12. Malav OP, Sharma BD, Gokulakrishnan P, Talukder S, Kumar RR (2012b) Effect of Water Chestnut Flour on the Quality Characteristics and Storage Stability of Restructured Chicken Meat Blocks. Fleisch Inter 27: 58-62.

13. Keeton J T (1983) Effect of fat and $\mathrm{NaCl} /$ phosphate levels on the chemical and sensory properties of pork patties. J. Food Sci 48: 878-881.

14. Snedecor GW, Cochran WG (1989) Statistical Methods. (8th Edition). IOWA State University Press, Ames, IOWA.

15. Kumar S (2007) Studies on processing of restructured turkey meat blocks. M.V.Sc. Thesis submitted to Deemed University, IVRI, Izatnagar, UP, India. 